\title{
'Not waiting for the initiative to arrive': Teachers promoting and sustaining reading
}

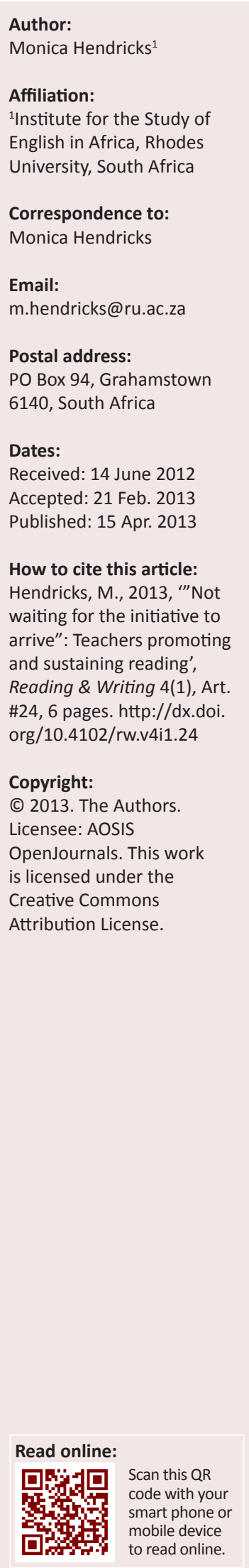

The phases of post-apartheid curriculum reform starting with Curriculum 2005, to the revisions ushered in by the National Curriculum Statements and the recent Curriculum and Assessment Policy Statements display a trend toward increasing prescription in terms of content to be taught and allocation of curriculum time per subject, both of which are useful. In order to prepare school teachers for these ongoing curriculum reforms and an increased assessment burden, the national and provincial Education Departments have held regular workshops and provided bursaries for teachers to embark on academic studies in their teaching field. In addition, estimates are that non-governmental sources have spent R1 billion annually since 1994 on school improvement and teacher development programmes.

\section{Introduction}

Despite these factors, teachers' limited content knowledge (Taylor \& Vinjevold 1999) and poor time on task (Hammerness et al. 2005) continue to bedevil South African schooling. It is self-defeating to criticise instrumental, performative criteria of teachers' and schools' performances, such as standardised learner testing and Integrated Quality Management Systems, without suggesting alternative ways to encourage and measure teacher professional development. Besides increasing regulation and performative criteria, which concentrate on external measurable outcomes, what is needed are ways in which to foster critical self-reflection and autonomy amongst teachers and researchers, so that learning is intrinsically motivated.

Recent theories of teacher professional development hold that teachers develop within communities of practice and that two different kinds of knowledge are important: knowledge learnt within teaching contexts (such as a university course) and knowledge developed within professional contexts (such as one's own classroom) (Hammerness et al.; Fine 2005:382). Whilst it is the norm for initial teacher education to combine these two knowledge areas, it is rarer for in-service, professional teacher development courses to do so. However, two in-service courses specialising in English First Additional Language at Rhodes University, an Advanced Certificate in Education and Bachelor of Education, bring together these two different knowledge areas. The university-based part of these courses focuses on building teachers' content knowledge, whilst in the school-based course component tutors observe lessons and guide teachers' reflections in order to build their pedagogical knowledge.

This article examines whether teachers who completed these courses were able to sustain the programme of reading for pleasure that they began during the course, once the course ended and they were on their own in their classrooms, no longer being mentored through regular classroom visits and shared reflections with a course tutor on a lesson observed. Given the evidence that many teachers are not proficient readers (Thomson 2009), was the regular reading teachers did as part of their studies sufficient for their own reading to be a habit? Had teachers learnt enough about the importance of reading for pleasure to continue to sustain their classroom libraries independently? What independent initiatives did teachers take to broaden their reading programmes?

Several aspects of the present educational context in South Africa make a powerful case for finding sustained and innovative ways of promoting and enhancing literacy in school. Foremost amongst these is learners' low levels of literacy in all South African languages (especially African languages) as evidenced in international tests such as the Progress in International Reading Literacy Study (PIRLS) (Howie 2002) and national tests such as the Annual National Assessment (Motshekga 2011). It is common knowledge that most poor Eastern Cape homes have little for children to read beyond a Bible and community libraries are rare in rural areas (Nelson Mandela Foundation 2005). This means that in order to develop grade-appropriate literacy, learners are almost completely dependent on their schools to provide them with books, and teachers to use 
those books effectively. Yet, unfortunately, whilst $92.77 \%$ of state schools nationally have no library materials or librarians (Equal Education 2010:21), the government is cutting budgets to school libraries and reducing the provision of non-textbook reading materials (Hoffman 2010:51).

Where books and reading materials are brought into schools (and there are many non-governmental organisations [NGOs] doing this, for example, Biblionef and Rally to Read, to name but two), language teachers are expected to operate school libraries and see to it that these resources get used because there is no national policy on school libraries or dedicated funding for such libraries, or librarians (Paton-Ash 2012). Much anecdotal evidence and research (e.g. Hunt 2007) suggest that books brought into a school without an existing library or programme of reading are often not used. Perhaps the reason is that the main responsibility to establish, resource and run a school library falls on the language teachers. These language teachers usually receive no training and are simply expected to take on this worthy, but extra, work in addition to coping with full teaching loads and ongoing curriculum changes (Chisholm et al. 2005).

\section{Teacher professional development and reading}

Hammerness et al. (2005:382) as well as the new Teacher Education Framework (Nzimande 2011) agree that teachers' professional development should include disciplinary learning (content knowledge) and practical learning (learning from practice or work-integrated learning). In order to build the English teachers' disciplinary knowledge and reading repertoire, the Bachelor of Education (BEd) and Advanced Certificate in Education (ACE) courses have a literature component that includes a range of fiction (poetry, novel, drama, short stories) and factual genres. Teachers are also required to spend an hour reading each day during course contact sessions, usually toward the end of the day, enjoying books they have chosen from a small classroom library, and are encouraged to continue with their own personal reading at home.

In terms of work-integrated learning, the teachers receive a set of classroom library books (from an NGO, such as Biblionef or the Zenex Foundation), and hands-on training about the practicalities of implementing an extensive reading programme with their learners, such as setting up accession registers and a book-borrowing system. Teachers are also introduced to classroom strategies aimed at promoting extensive reading, for example, paired reading, and activities such as creating a log of new words and favourite quotes from books read (Gawith 1990), and tasks to link reading and writing, such as book reviews. Finally, teachers have an assignment, spaced over 18 months, which requires them to write a report on their extensive reading programme and to track six learners' progress. For the duration of their studies, therefore, teachers have a certain obligation to promote extensive reading in their classrooms.
In 2010, I had an opportunity to find out whether teachers promote and sustain their reading programmes as the Institute for the Study of English in Africa (ISEA) hosted a conference, mainly for alumni of our teacher education programmes. From 2003-2009, the ISEA had 65 ACE and 27 BEd graduates from its teacher professional development programmes, who came from districts including Bizana, Butterworth, Fort Beaufort, Grahamstown, King Williams Town, Lusikisiki and Mount Fletcher. These alumni were invited to write a report on how they had sustained their extensive reading programmes. They were given a writing frame and about three months to write their reports. Seven teachers handed in written reports of their reading programmes at the 2010 conference, several with accompanying photographs, and one teacher presented a verbal report at the conference. Early in 2011, another teacher (making a total of nine) invited the ISEA to the launch of his reading programme at his new school. It was a formal event, attended by teachers and learners, parents and district officials. I interviewed him about his reading programme. So, nine out of 92 ISEA alumni, just fewer than $10 \%$, could provide evidence of independent, autonomous action to promote reading for pleasure with their learners.

\section{Research methodology, questions and theoretical framework}

The first seven teachers gave consent for me to copy the reports that they presented at the conference and conduct a document analysis for research purposes. I interviewed the remaining two about their reading programmes and they consented to my using the interview data. Not a single teacher requested anonymity; instead, all were keen to have their names and photographs included in any report or conference paper that I wrote. I therefore provide the names of the teachers. I include the districts in which they taught to indicate their geographic spread and mainly rural location in the Eastern Cape. I do not, however, name their schools.

As I was interested primarily in understanding how and why these teachers had sustained their reading programmes, some of the questions investigated include:

- Which teachers sustain their classroom libraries and reading for pleasure programmes?

- What enables some teachers to sustain their classroom libraries and reading for pleasure programmes independently?

- Do teachers who sustain their extensive reading programmes have a supportive collegial circle?

Early models of professional development (e.g. Fuller \& Brown 1975) posited developmental stages:

survival, mastery and, finally, a stage where student teachers either settle into routines and become resistant to change or they become ... concerned about their impact on pupils and responsive to feedback about their teaching. (Quoted in Furlong \& Maynard 1995:68)

Whilst these stages confirm my experience of how teachers develop, they do not explain why some teachers remain at stage one or two, or how a teacher can move from one stage to the next. 
The advantage of the Hammerness et al. (2005) model is that it provides a more dynamic understanding and analysis of teacher professional development. Hammerness et al. (2005:385) propose a model of teacher professional development which highlights the contextual factors and relationships that enable or constrain teacher professional development. Their model suggests five dimensions that 'competent beginners and accomplished teachers need to know and be able to do in order to teach challenging content to diverse students'. These five interrelated dimensions are:

- Understanding (deep knowledge of content, pedagogy and students).

- Practices (developing, practising and enacting a beginning repertoire).

- Tools (conceptual and practical resources for use).

- Dispositions (habits of thinking and action regarding teaching).

- Vision (images of the possible) (Hammerness et al. 2005:386).

Finally, the model proposes that these five interrelated dimensions of teacher professional development operate within a learning community.

This model was employed as an analytical tool in order to analyse teachers' reports about their reading programmes because it enabled one not only to differentiate between disciplinary and practical learning, but also to identify elements of the teachers' professional identity. The categories of Dispositions (habits of thinking and action regarding teaching) and Vision (images of the possible) form the core of teachers' professional identities and animate their 'teacherly' disciplinary and practical knowledge. My aim in employing this model was to identify and understand what motivated these teachers to act independently and autonomously, rather than in response to regulations.

\section{Findings: 'Not waiting for the initiative to arrive'}

Of the nine teachers whose reports I analysed, four taught in the Mount Fletcher district, two in the Fort Beaufort district and one each in the Bizana, King Williams Town and Lusikisiki districts. Their reports are analysed in terms of the five dimensions of the Hammerness et al. (2005) model:

- Understanding

- Practices

- Tools

- Dispositions

- Vision.

Also, I considered the extent to which these teachers formed, or considered themselves part of, a learning community with regard to reading for pleasure.

\section{Understanding}

In his report, Mr Bushula of Fort Beaufort articulates an Understanding, not only of professional knowledge (a systematic, step-by-step pedagogy), but also a researchinformed, academic knowledge of the purpose of reading for pleasure:

'Research has shown that reading provides the opportunity for learning to occur outside the classroom and that there is a wide range of learning benefits from reading. Having that in mind, I decide to use the books that were donated by Zenex Foundation to form a classroom library.

As a language teacher, I knew that extensive reading was one of the weapons to develop my learners' proficiency in second language ...

A good teacher always knows his/her learners. I decided to embark on an implementation plan so as to enable the extensive reading programme to make progress. Firstly, I decided to choose a variety of books according to their levels. Secondly, I introduced the books to the learners ... Thirdly, I gave my learners the books to read silently. The fourth step was to incorporate other activities that promoted reading, e.g. discussions and reviews that were based on the books that they were reading. The fifth step was to introduce strategies that were helpful in extensive reading, e.g. library orientation and frequent visits to the public library.' (Mr Bushula)

\section{Practice}

Ms Ndamase's report on her extensive reading programme provides compelling evidence of reading as a habit, a regular Practice, in her Grade 4 and 5 class in the Lusikisiki district. According to the report, children are sitting and reading, engrossed in the activity. Three boys are completely focused on their books: their body posture is relaxed, with one bent over his book. All are intent on their reading and none appears to notice when their teacher takes the photograph. Sustained, independent reading in this class is familiar, comfortable and enjoyed.

Further examples of Practices associated with reading were reported by Mr Mafunda (Mount Fletcher), Ms Nomangola (Mount Fletcher) and Ms Ndovela (Bizana). Their learners participate eagerly in debates, language festivals and reading activities such as Library Week. Mr Bushula's learners and school were involved in a language festival on Heritage Day, literacy days and are often given an opportunity to comment at the school assembly on recent news that made headlines.

\section{Tools}

Practices need to be sustained by Tools, both material and conceptual. Amongst the most important material tools are books, both textbooks and non-textbooks, to read for pleasure. All these teachers made efforts to find more reading resources by asking colleagues and community members for books and magazines to add to their small classroom library stock. Mr Kepe (King Williams Town) is an example of a teacher with the conceptual tools (a conviction of the importance of reading for pleasure) who found the material tools to realise his vision.

In 2009, a year after Mr Kepe graduated from the ACE course, his school, together with the donation of classroom 
library books he received as an ACE student, was destroyed in a storm. Without a school, Mr Kepe spent about three months reporting to the district office as a displaced teacher. Eventually, in April 2010, he was deployed to another school in the same district which had no non-textbooks for learners to read for pleasure. Despite being new at the school, $\mathrm{Mr}$ Kepe was so convinced of the benefits of extensive reading that he initiated a school reading club from scratch. He started with a small donation of books from an Eastern Cape Provincial official involved in adult education. The books were in English and isiXhosa, which may explain why he was able to interest not only colleagues who taught English but also isiXhosa teachers. Just over a year after joining his new school, Mr Kepe was able to launch a school reading club.

Some teachers, for example Mr Setsubi (Mount Fletcher) and Ms Ndamase, wrote to NGOs such as Soul City and Love Life and asked Education District officials for books. Mr Setsubi, especially, has been extremely successful in acquiring books and resources for his very big school.

Ms Nomangola, like Mr Kepe, was a teacher who moved from her original school to a new school in the same district, but her reactions are strikingly different. In her original fairly small remote school, she was encouraged to maintain her extensive reading programme because she and other teachers saw the benefits for learners. She and other colleagues attributed the improved matric results between 2004 and 2007, an increase from $20 \%-30 \%$ to $50 \%$, to the learners' additional reading at school.

Then, in 2008, she moved to a bigger school, which had books from Biblionef and two mobile libraries donated by Telkom. The material tools for extensive reading were there, but the teachers' practice was to focus exclusively on reading prescribed books. She writes:

'In the new school I felt very small because it was a bigger school as compared to the one I was coming from. I decided to wait and copy the style of the teachers who were already there. I waited for them to tell me about Biblionef but they didn't. In their styles they used to do the first few chapters [of the prescribed books] with the learners thoroughly e.g. to work for the character and analyse them, the setting of the story, the style of the author and then allow the learners to read on the following chapters on their own and prepare themselves for the assignments and tests'. (Ms Nomangola)

The following year, a fellow English teacher was trained as a librarian, but the library books were still not used. It was only in 2010, after a visiting academic based at the ISEA (Dr Eva Yerende), went to Mount Fletcher and enquired at her new school about reading that Ms Nomangola was motivated:

As from the day I was visited by Dr [Yerende] from Rhodes I felt renewed again ... We [she together with the English teacher/ librarian] started to count [the books] and they are 200 books: 70 novels, 80 short stories and 50 drama books. They are all written in English as our school is using English as a medium of instruction. Learners are going to use them for the extensive reading.

\section{Disposition}

How does Understanding become part of teachers' Disposition? In this instance, do teachers themselves read for pleasure and are they authentic reading models capable of enthusing others (colleagues and learners) to read? Three teachers in particular expressed how they lived and actualised their disposition as readers:

'I always encourage teachers from grade $\mathrm{R}$ up to grade 9 to encourage learners to go to the library for information, [rather] than to always ask information from teachers and elders'. (Mrs Batyo-Qithi)

'I believe that teachers should first read the books before introducing them to the learners. Teachers should be readers themselves'. (Mr Bushula)

Mr Setsubi regularly brings 150 copies of the local free newspaper, East Griqualand Fever, to school and, together with the other language teachers, formed a Book Club where 'teachers bring their old books they have read, magazines to read at school and we circulate these'.

\section{Vision}

All nine teachers demonstrate Vision-an image of themselves and their learners as people who read for pleasure. Such a vision should not be assumed, given the rural Eastern Cape context where, as noted, homes have little for poor children to read, community libraries are rare (Nelson Mandela Foundation 2005) and only a tiny number of schools have libraries (Equal Education 2010). What is interesting is not only these teachers' vision of themselves and their learners as readers, but the ways in which they instil this vision. They are reading enthusiasts and individuals who are highly motivated to find extra books for their fledgling school libraries. Mr Rala (of Fort Beaufort) who described himself as 'not waiting for the initiative to arrive' articulates this independence and autonomy. Then there is Mr Kepe, who took active steps to realise this vision at a new school with no books to read for pleasure, whilst Mr Bushula could enthuse his colleagues and extend his classroom reading project into a whole-school reading club. Mr Mafunda envisages his learners and parents as not only as readers, but as writers - he developed a newsletter to publish community stories.

With regard to forming a learning community, the distances between dispersed rural schools, generally poor road surfaces, unreliable telephone connections and unstable internet connectivity all make it difficult for these teachers to stay in touch and form a community of people who like to read and promote reading for pleasure at their schools. Despite the challenges of a rural context, all nine teachers, to varying degrees, collaborated with their colleagues, motivated them to join in promoting reading for pleasure at their school and thereby forming a learning community. Mr Kepe and Mrs Batyo-Qithi included not only their immediate school colleagues but also university-based colleagues, parents and Education District officials as part of their reading learning community: 
'In 2008, my school was chosen as a centre for a 'Cluster library'. I was given a half triangle in this classroom and the shelving was erected. There is a librarian in our district now who also encouraged me to make the library active'. (Mrs Batyo-Qithi)

Forming a learning community is perhaps the most important part of the Hammerness et al. (2005) model because such a community is a space for sharing innovations and best practices, the key to teachers' taking initiative and becoming self-regulating, autonomous agents. When the intellectual stimulation and critical feedback provided by formal tuition subsides, Darling-Hammond and McLaughlin (1995) suggest that teachers need to develop learning communities at their schools.

\section{Implications for ongoing teacher professional development}

Teachers need sustained professional support in order to improve their classroom literacy practices, beyond what a two- or three-year course can offer (Darling-Hammond \& McLaughlin 1995). Such a supporting network for teachers' professional development could include Education District officials, university-based academics and professional associations.

The establishment of permanent forums for the nurturing of ongoing professional development is critical and there are several encouraging signs that teachers are developing associations where the professionalisation and transformation of educational practice can flourish. As an example, the Eastern Cape English Educators' Association was launched in 2010 (Wright 2010).

National policy and adequate funding for school libraries and librarians are needed to address the problematic fact that many school (and classroom) libraries fall into disuse because over-burdened language teachers fail to find the time to keep them functioning. Paton-Ash (2012) suggests that a dedicated librarian is necessary, not only for a school library to function properly, but also to shift common perceptions amongst teachers that libraries and regular reading are peripheral to learning and literacy.

Another possibility to promote reading and the use of books in schools may be the Presidential Expanded Public Works Programme, which may provide an innovative means of bringing together the nexus of thousands of unemployed young people (Paton 2010) and the many over-loaded teachers (Chisholm et al. 2005). Many young people on the Expanded Public Works Programme are assigned to schools and Education District offices as clerks. Rather than this empty title, it may be more useful for schools, and more productive for the youth, for them to have a job description such as literacy coach so that they have a more specific, educational role in schools.

Whilst problems of low literacy pervade the entire schooling system, the most effective point to make a difference is in primary schooling, particularly at the Foundation and Intermediate Phases - within the early years (Caswell \& Glover 2004). I believe that young people who have matriculated have a sufficient level of literacy to be able to be trained and guided in order to function as literacy coaches for children in the early years of school. Not only would such literacy coaches be authentic, local reading models where these are scarce, but their own reading skills would be enhanced and teachers would have some support in running school libraries and extensive reading programmes.

\section{Conclusion}

Without a rigorous tracker study, it is impossible to know the exact number of teachers who continue to promote reading for pleasure in their classrooms. It is telling that once their academic course is over, this evidence suggests that barely $10 \%$ of these teachers could provide evidence of their ability to sustain a reading programme, or initiatives to promote reading for pleasure at their schools. This does not necessarily mean that $90 \%$ of teachers require regulation, but rather that most teachers need learning communities at their schools and districts, a supportive network of Education District officials, specialist librarians and university-based academics, and professional associations.

The answers to the two related questions posed earlier, about what enables some teachers to sustain their classroom libraries and reading programmes independently and whether teachers who sustain their extensive reading programmes have a supportive collegial circle, are complicated.

The collegial ties that teachers form during an academic course of study do not necessarily foster a learning community of the sort envisaged by Hammerness et al. (2005). Neither does such study enable an individual teacher to continue his or her own personal reading, or sustain a classroom-based reading programme. The essential driver of that capacity likely relies on both teachers' and teacher educators' intrinsic motivation to read and, through lived experience, their ability to ignite that enjoyment and sense of purpose in their classrooms.

\section{Acknowledgements Competing interests}

The author declares that she has no financial or personal relationship(s) which may have inappropriately influenced her in writing this article.

\section{References}

Caswell, L. \& Glover, T., 2004, Becoming Lovers of Books: Student Literacy Outcomes in a Literacy Collaborative School, Center for Reading Recovery and Literacy Collaborative, Lesley University, Cambridge, MA.

Chisholm, L., Hoadley, U., Wa Kivulu, M., Brookes, H., Prinsloo, C., Kgobe, A., Mosia, D., Narsee, H. \& Rule, S., 2005, Educator Workload in South Africa, HSRC Press, Cape Town.

Darling-Hammond, L. \& McLaughlin, M., 1995, 'Policies that support professional development in an era of reform', Phi Delta Kappan 76(8), 597-604, viewed 28 October 2011, from http://www.oest.oas.org/iten/documentos/Investigacion/ randd-engaged-darling.pdf

Equal Education, 2010, We Can't Afford Not To, Two Tone Printers, Cape Town. 
Fuller, F. \& Brown, O., 1975, 'Becoming a Teacher', in K. Ryan, Teacher Education, 74th yearbook of the National Society for the Study of Education, National Society for the Study of Education, Chicago.

Furlong, J. \& Maynard, T., 1995, 'Stages of student development', in J. Furlong \& T. Maynard (eds.), pp. 68-99, Mentoring Student Teachers, Routledge, London.

Gawith, G., 1990, Reading Alive!, A\&C Black Publishers, London.

Hammerness, K., Darling-Hammond, L., Bransford, J., Berliner, D., Cochran-Smith M., Mcdonald, M. \& Zeichner, K., 2005, 'How teachers learn and develop', in L. Darling-Hammond \& J. Bransford (eds.), pp. 358-389, Preparing Teachers for a Changing World, Jossey-Bass, San Franscisco.

Hoffman, R., 2010, 'Cut only the fat', Mail and Guardian, 3-9 December 2010, p. 51.

Howie, S., 2002, English Language Proficiency and Contextual Factors Influencing Mathematics Achievement of Secondary School Pupils in South Africa, Universiteit Twente, Twente.

Hunt, G., 2007, 'Failure to thrive? The community literacy strand of the Additive Bilingual Project at an Eastern Cape Community School, South Africa', Journa of Research in Reading 30(1), 80-96. http://dx.doi.org/10.1111/j.14679817.2006.00327.x
Motshekga, A., 2011, 'Statement on the release of the Annual National Assessments Results for 2011', viewed 21 October 2011, from http://www.info.gov.za/speech/ DynamicAction? pageid $=461 \&$ sid $=19525 \&$ tid $=36106$

Nelson Mandela Foundation, 2005, Emerging Voices, HSRC Press, Cape Town.

Nzimande, B., 2011, Policy on the Minimum Requirements for Teacher Education Qualifications, Department of Higher Education and Training, Pretoria.

Paton-Ash, M., 2012, 'Issues and challenges facing school libraries: A case study of selected primary schools in Gauteng Province, South Africa', unpublished Master of Education half-thesis, Rhodes University, Grahamstown.

Paton, C., 2010, 'Time bomb', Financial Mail, 25 March 2010, viewed 10 May 2010, from http://www.financialmail.co.za/Article.aspx?id=104597

Taylor, N. \& Vinjevold, P., 1999, Getting Learning Right, Joint Education Trust, Johannesburg.

Thomson, C., 2009, '"Living" sacrifice and shame: Phenomenological insights into continuing, "distanced" education student experience', South African Journal of Higher Education 23(4), 795-808.

Wright, L., 2010, 'Why English Teachers Need Professional Associations', Teaching English Today, 1.1., viewed 10 February 2012, from http://www.teachenglishtoday.org 